\title{
Estimation of the Values of Wooden Materials in Urban Regeneration: The Case of Seoullo in Korea
}

\author{
Heesun Lim ${ }^{1}$, Chang-Deuk Eom ${ }^{2}$ (i) and Byeong-il Ahn ${ }^{1, *(1)}$ \\ 1 Department of Food and Resource Economics, Korea University, Seoul 20841, Korea; hslim0831@korea.ac.kr \\ 2 National Institute of Forest Science, Seoul 02455, Korea; willyeom@korea.kr \\ * Correspondence: ahn08@korea.ac.kr
}

Citation: Lim, H.; Eom, C.-D.; Ahn, B.-i. Estimation of the Values of Wooden Materials in Urban Regeneration: The Case of Seoullo in Korea. Sustainability 2021, 13, 9810. https://doi.org/10.3390/su13179810

Academic Editor: Andrea Pérez

Received: 19 July 2021

Accepted: 24 August 2021

Published: 1 September 2021

Publisher's Note: MDPI stays neutral with regard to jurisdictional claims in published maps and institutional affiliations.

Copyright: (c) 2021 by the authors. Licensee MDPI, Basel, Switzerland. This article is an open access article distributed under the terms and conditions of the Creative Commons Attribution (CC BY) license (https:// creativecommons.org/licenses/by/ $4.0 /)$.

\begin{abstract}
The importance of wooden buildings has been highlighted in recent years due to the energy-efficient and carbon storage effect of wood. This study investigates the willingness to pay for one-time tax payments of the citizens currently living in Seoul when Seoullo uses wood as a material for covering the surface of the facilities. The study examines the economic feasibility of Seoullo, which is a part of the government urban regeneration project that built a park on the desolate bridge in 2017. The result indicates that Seoul citizens who participated in the survey feel a greater preference for wood material rather than existing concrete used in Seoullo despite the tax burden. As a result, it is found that the respondents with children under the age of 8 , respondents who are aware of the urban regeneration project, and respondents with respiratory disease have a lower marginal willingness to pay than those in the opposite groups. Moreover, the result shows that the respondents who consider farming or returning to rural areas, respondents in need of city improvement, respondents who chose wood as a preferred building material, and respondents with the experience of visiting Seoullo have a greater marginal willingness to pay for the wooden material than those in the opposite groups.
\end{abstract}

Keywords: urban regeneration project; wood; sustainability; choice experiment; sustainable development; consumers' preferences

\section{Introduction}

The continuous increase in carbon dioxide emissions around the world is a widespread problem due to economic growth driven by an increase in the usage of fossil fuels. Carbon dioxide, one of the main causes of climate change, was emitted 32.5 billion tons in 2017 [1]. The rate of increase in carbon dioxide emissions is increasing rapidly in Asia. As a result, the government's interest in the urban regeneration project is shifting to environmental-friendly materials that absorb carbon, and the importance of wood as a sustainable construction material has been highlighted.

Buildings or houses made of wood have existed since the past due to warm material characteristics, leading the evolution of the aesthetic aspect of architecture [2]. Even though the disadvantages of wooden material such as high combustibility, low durability, and high construction cost persist in the minds of consumers, consumers have a high preference for aesthetics, manageability, harmony with nature, traditional tendency, well-being, and luxurious ambiance aspects of wooden buildings [3,4]. Recently, consumers' interest in wood is higher than before because consumers are paying attention to environmental aspects such as the energy efficiency and carbon storage effect of wood. This implies that the interest in wood as a sustainable construction material is increasing in trend from both consumers and government sectors [3].

Wood as a construction material meets the global agenda of sustainable development with the effect of reducing carbon dioxide. The term sustainable development was first introduced at the 1992 Earth Summit in Rio. The Rio +20 Conference held in 2012 highlighted sustainable cities as one of seven areas that needed priority attention. Previous research 
shows that the construction of cities and buildings using wood, a sustainable resource, contributes to maintaining and developing a sustainable society [5-8]. However, the supply of wood used for construction may face challenges by factors affecting the supply, such as deforestation, acid rain, and the destruction of natural habitats. [9].

At the government level, the use of wood in public buildings is emerging as a new project to revitalize the wood industry. In a broad sense, the vitalization of the wood industry leads an eco-friendly culture in the era of climate change. In addition, in the narrow sense, the use of wood in public buildings will be part of an urban plan to redevelop a run-down city surrounded by high-rise apartment buildings. The urban regeneration project using wood aims to construct a wooden structure that can solve the climate change problem through long-term carbon storage [2].

Government policies play a pivotal role in supporting urban regeneration projects that provide public goods. It is not only for the benefit of one individual but also for the benefit of the majority of citizens. A city project using wood means turning an old city into a livable and eco-friendly city. Through this, it can contribute to improving the quality of life of citizens and revitalizing the domestic timber industry by creating mass demand for wood. In addition, long-term use of wood can reduce greenhouse gas emissions. As an example of a city project using wood, this paper introduces Seoullo, a representative urban regeneration project in Korea. Seoullo is a $1027 \mathrm{~km}$ long pedestrian overpass built in 2017 on a deserted bridge near Seoul Station in the center of Seoul. Seoullo is a park with a concrete floor in harmony with the surrounding buildings and various trees and flowers that have been planted. Seoullo provides a resting space for citizens and enables movements around Seoul Station, and holds various cultural exhibitions, as tourist information and convenience facilities are located throughout the overpass.

There are some previous studies capturing monetary incentives to reforest rural communities [10] and public attitudes toward urban wood [11]. However, the research on the effects of constructing buildings by utilizing wood has not been actively conducted. Moreover, a quantitative evaluation of how much citizens are willing to pay for an urban project utilizing wood in the form of one-time tax payment has not been conducted yet. This study fills the gap of existing literature by focusing on the preference of consumers toward the urban regeneration project which utilizes wood as the main construction material. This study also contributes to the literature since it derives the construction cost and estimates the economic feasibility of the urban regeneration project using a benefit-cost analysis. In this context, this paper is expected to be used as the practical and useful evidence for promoting and improving the policies regarding regenerating the desolate areas.

\section{Literature Review}

Wood is a sustainable building material in building construction and is gaining popularity among policymakers and the stakeholders in the construction sector [12-15]. Despite the importance, consumer-driven approaches based on consumer preferences and perceptions occupy only a small portion of the discussion due to the lack of previous research that has been done on this matter. Kylkilahti et al. [16] surveyed Finnish students' perceptions of multi-story wooden buildings and found that aesthetic appearance, comfort, and environmental aspects were highly valued among students. There are also few studies on the other uses of wood as a sustainable material. Ouvrard et al. [17] analyzed the impact of conveying different information regarding wood ash recycling on the willingness to pay for wood ash application. The conveyed information highlights aspects of environmental protection, wood recycling, and increased wood production.

The positive impacts of wood-based buildings on the environment suggest that wood can cope with climate change as a sustainable building material. Švajlenka and Mária [18] used life-cycle assessment and costs as variables to measure economic and environmental effects by comparing non-wood and wooden buildings. As a result, it was shown that modern buildings based on wood have an advantage in terms of impact and cost to the environment. Jang [19] claimed that wood materials used for construction can solve the 
climate change issue. He provided the evidence by quantifying the carbon fixation and fossil fuel substitution effects of wood. Roh [2] reiterated that the demand for wooden buildings that have a positive impact on the environment, such as preventing global warming and resolving building waste, is increasing.

Despite the positive effects of wood-based buildings from an economic and environmental aspect, the cost of using wood materials is high. Therefore, it is important to examine the economic feasibility of urban regeneration projects and to estimate the willingness to pay for public goods from the point of view of the government and citizens. Recent studies include a cost-benefit analysis of urban regeneration and renewal interventions $[20,21]$. Moreover, the effect of the improvements of neighborhoods as positive externalities brought by the urban regeneration process [22] and the implicit value attributed to the impact of heritage policies within the historic district [23] are actively discussed. Most of these studies investigate the justification based on the economic feasibility of urban regeneration policy through drawing citizens' interest in improving health, safety, and the natural environment. However, urban regeneration projects may have nonpecuniary benefit components that are not measurable [24-26].

\section{Materials and Methods}

\subsection{Empirical Model and Calculation of Costs}

\subsubsection{Empirical Model for Estimating Willingness to Pay}

A Choice Experiment is a methodology that analyzes the choice of maximizing one's utility among given alternatives for a hypothetical product. The model combines the attributes of a specific product through a random utility model [27]. In the same vein, Contingent Valuation and Experimental Auctions, including Choice Experiment (CE), are the most commonly used methodologies for analyzing consumers' willingness to pay [28,29]. Through these analytical tools, information on consumer demand and preference can be obtained. The result shows how much preference consumers have for each attribute and how much they intend to pay for each attribute. Seoullo has already been built using concrete, but we set up a hypothetical situation where Seoullo is refurbished by covering the surfaces of the five attributes such as floor, bridge fence, flowerpot, bench, public facilities using wood. Using the Conditional Logit Model, this study examines the willingness to pay (WTP) of Seoul citizens when each attribute of Seoullo is built using wood rather than the existing concrete.

Using the Random Utility model, the representative citizen $i$ 's utility $\left(U_{i j}\right)$ for alternative $j$ can be expressed as Equation (1). Since we cannot directly observe the citizen's utility, we can calculate the effect of a change in a specific attribute based on the respondent's response through the utility model using probability. The citizen's utility $\left(U_{i j}\right)$ for alternative $j$ consists of an indirect utility $\left(\mathrm{V}_{i j}\right)$ and an error term $\left(\epsilon_{i j}\right)$. The deterministic utility, $V$, is determined by the attribute level of an alternative $\left(Z_{j}\right)$, citizens' socioeconomic characteristics $\left(X_{i}\right)$, and the error term. While $\beta$ is the coefficient vector representing the result of all respondents, $\alpha$ is the coefficient vector representing the results of subgroup respondents [30].

$$
U_{i j}=V_{i j}+\epsilon_{i j}=Z_{j} \beta+X_{i} \alpha+\epsilon_{i j}
$$

where $S_{i}$ denotes possible combinations of all profiles. The probability that the specific profile selected by the citizen will bring the maximum utility can be expressed as the following equation.

$$
P_{i j}=P\left(\mathrm{~V}_{i j}+\epsilon_{i j} \geq \mathrm{V}_{i k}+\epsilon_{i k} ; k \in S_{i}\right)
$$

If the error term $\left(\epsilon_{i j}\right)$ is independently and identically distributed following an extreme value (Gumbel) distribution, the probability that the citizen $i$ will choose $j$ from $k$ choice combinations is shown in Equation (3).

$$
P_{i j}=\frac{\exp \left(V_{i j}\right)}{\sum_{k=1}^{N} \exp \left(V_{i j}\right)}=\frac{\exp \left(Z_{j} \beta+X_{i} \alpha\right)}{\sum_{k=1}^{N} \exp \left(Z_{j} \beta+X_{i} \alpha\right)}
$$


The indirect utility $\left(V_{i j}\right)$ can capture the magnitude of the citizen's utility by a linear additive model that links $m$ attributes of an alternative $\mathrm{j}\left(Z_{j} \cdots Z_{j m}\right)$, socioeconomic characteristics $\left(X_{i} \cdots X_{i m}\right)$, and parameters $\left(\beta_{1} \cdots \beta_{m}\right.$ and $\left.\alpha_{1} \cdots \alpha_{m}\right)$, which can be expressed as Equation (4).

$$
V_{i j}=Z_{j} \beta_{1}+X_{i} \alpha_{1}+\ldots+Z_{j m} \beta_{m}+X_{i m} \alpha_{m}
$$

The WTP for the marginal change of a specific $m$ th attribute for all respondents is calculated by the ratio of the parameter estimate $\left(\beta_{m}\right)$ and the price parameter $\left(\beta_{p}\right)$ as shown in Equation (5). The numerator of the ratio is derived by dividing the differential of indirect utility and the differential of $m$ th attribute of an alternative $j\left(Z_{j m}\right)$. The denominator of the ratio is derived by dividing the differential of indirect utility and differential of the price attribute of an alternative $j\left(Z_{j p}\right)$.

$$
W T P=\frac{d V / d Z_{j m}}{d V / d Z_{j p}}=-\frac{\beta_{m}}{\beta_{p}}
$$

\subsubsection{Derivations of Construction Costs and One-Time Tax Payment}

In this study, the economic feasibility of the Seoullo project is investigated using benefit-cost analysis. Prior to the design of the survey for the choice experiment, the cost of using wood rather than the existing concrete material for Seoullo is calculated. The total material cost (CM) for refurbishing Seoullo with wood can be obtained through the following Equation (6).

$$
C M=\left(\frac{S A}{W A}\right) \times W P
$$

The total wood material cost $(\mathrm{CM})$ is calculated by multiplying the number of wood panels to be used and the price of the wood panel (WP). Moreover, the number of wood panels is calculated by dividing the surface area of Seoullo (SA) by the area of a single wood panel (WA). As for the price of the wood panel, an average market price of KRW 9.73 (The presented price is the average of the treated wood deck which has the size of 3.9 in * 141.7 in $^{*} 0.8 \mathrm{in}$. (width ${ }^{*}$ length ${ }^{*}$ height)) is applied. The surface area of Seoullo is calculated to be $113,529 \mathrm{ft}^{2}$, and the area covered by a single wood panel is $3.88 \mathrm{ft}^{2}$. Applying these values, the number of wood panels to be used for covering Seoullo is estimated to be 29,298. Therefore, the calculated total material cost of using wood is 285,008 dollars.

Equation (7) indicates the total construction cost (TC) for Seoullo, which is calculated by adding up the total material cost (CM) with the construction labor cost (LC). TC is derived according to the scenarios of building Seoullo with wooden materials. In the construction industry, it is known that the labor cost generally accounts for about 35\% of the total cost. Using this information and the derived wood material cost, the construction labor cost is calculated to be 153,466 dollars. Thus, the total construction cost is calculated to be 438,474 dollars. In this study, the derived construction cost is set as a base scenario.

The base scenario does not account for the difference in construction for a building between using wood and concrete. It takes a longer time to use wood for constructing a building and requires professional construction labor that has wood construction techniques. The baseline construction cost does not include the cost of wooden materials to be used for other structures such as fences, benches, and public facilities. Therefore, more labor and material costs would be required. By reflecting this point, the total construction cost of Seoullo is assumed to be about 1.5 or 2 times larger than the calculated baseline cost of KRW 438,474. Thus, cost scenarios 1, 2, and 3 are set as 438,474 won, 657,711 won and 876,948 won, respectively.

$$
\mathrm{TC}=\mathrm{CM}+\mathrm{LC}
$$

The amount of a one-time tax payment per household can be calculated by dividing the total construction cost by the number of households in Seoul. According to Korean Statistical Information Service data as of September 2020, the total number of households in Seoul is $9,699,232$. Therefore, using the calculated total construction cost of 438,474 dollars 
and the number of households in Seoul, the amount of cost burden (such as one-time tax) per household is derived to be 0.04 dollars However, this amount is too low to be perceived as a realistic one-time tax payment per household. Therefore, this study conducted a preliminary survey by asking citizens about the amount of realistic one-time tax for the Seoullo project. The surveyed one-time tax amount is used for composing the level of price attributes of Seoullo in the questionnaire.

\subsection{Data}

In order to select the attributes of Seoullo, a specialized research institute, the Cognitive Consulting Group conducted a preliminary survey on the citizens living in Seoul. We asked Seoul citizens about attributes that most influence Seoul citizens' choice decisions for Seoullo. The result of preliminary survey shows that citizens chose floor, bridge fence, flowerpot, bench, and public facilities as attributes that most influence their choice. Moreover, we included the price attribute which represents the amount of the one-time tax payment of citizens (see Table 1).

Table 1. Attributes used in the choice experiment.

\begin{tabular}{cc}
\hline Attributes & Levels \\
\hline Floor & Wood, Concrete \\
Bridge fence & Wood, Concrete \\
Flowerpot & Wood, Concrete \\
Bench & Wood, Concrete \\
Public facilities & Wood, Concrete \\
One-time tax (KRW) & 2000 won, 4000 won, 6000 won, 8000 won, \\
& 10,000 won (USD 1.8, 3.5, 5.3, 7,8.8)
\end{tabular}

Note: the average exchange rate (1141 won/USD dollar) in July 2021 is applied.

The levels of the attributes of the floor, bridge fence, flowerpot, bench, and public facilities are composed of two levels which are wood and concrete. Based on the results of a preliminary survey, the average amount of one-time tax to pay for the construction of Seoullo with wood material was calculated to be USD 5.08. Using this result, the attribute levels of the one-time tax for the choice experiment were chosen as USD 1.8 dollars, 3.5 dollars, 5.3 dollars, 7 dollars, and 8.8 dollars.

An orthogonal fractional factorial design was used to determine 16 pair choice profiles out of the total 160 profiles, which can be obtained by multiplying the levels of all six attributes $2 \times 2 \times 2 \times 2 \times 2 \times 5$.

Survey questionnaires include demographic characteristics such as gender, age, marital status, monthly household income, and the status of whether or not having children under the age of 8 . The question regarding personal health conditions is also included in the survey, since the incidence of respiratory diseases is increasing due to fine dust [31,32], especially in Korea. Marois et al. [33] found that residential mobility of seniors after retirement shows the largest number in suburban areas, and these mobilities occur due to the death of a spouse or health problems. Based on this result, the question regarding the consideration of farming or returning to a rural area after retirement is included. Oh et al. [34] analyzed the impacts of awareness of the urban regeneration project on place attachment and found a positive correlation between the two. In order to reflect the awareness of urban regeneration projects, questions regarding the awareness of urban regeneration projects, the need for city improvement, and the experience of visiting Seoullo are included in the questionnaire.

The choice questionnaire is composed of a total of 8 questions, and respondents can choose options A, B, or no choice option. The questions differ in attributes and levels, and we ask each respondent about the preference on the presented combination of attributes of Seoullo. Moreover, the no choice option is added to reflect the reality where consumers do not wish to make any choices between presented options A and B. 
For this study, a survey was conducted on 535 Seoul citizens for 19 days from 2-20 October 2019. Survey questionnaires were sent via email to respondents. According to the socioeconomic characteristics of the survey respondents, men and women are $57 \%$ and $43 \%$, respectively with 329 married (61\%) and 206 being single (39\%) (see Table 2). While 74\% of the participated respondents have a bachelor's degree, the number of household members living together is the highest in the group of three (34\%). The age distribution is similar across each different age group at around $20 \%$ except for over 70 with 36 respondents $(7 \%)$. While $88 \%$ of the respondents do not have children under the age of $8,52 \%$ of the respondents' occupation is shown to be an employee. The monthly average household income is the highest in the group of over 5055 dollars with 139 respondents $(26 \%)$. The unit of the survey data and analysis result is the Korean won, and the average exchange rate (1187.3 won/US dollar) in August 2020 is applied.

Table 2. Socioeconomic Characteristics of the Respondents.

\begin{tabular}{|c|c|c|c|c|c|c|c|}
\hline \multicolumn{2}{|c|}{ Classification } & \multirow{3}{*}{$\begin{array}{c}\begin{array}{c}\text { No. of } \\
\text { Respondents }\end{array} \\
306 \\
229\end{array}$} & \multirow{3}{*}{$\begin{array}{c}\text { Ratio (\%) } \\
57 \\
43\end{array}$} & \multicolumn{2}{|l|}{ Classification } & \multirow{3}{*}{$\begin{array}{c}\begin{array}{c}\text { No. of } \\
\text { Respondents }\end{array} \\
43 \\
89\end{array}$} & \multirow{3}{*}{$\begin{array}{c}\text { Ratio (\%) } \\
8 \\
17\end{array}$} \\
\hline & Male & & & \multirow{6}{*}{$\begin{array}{l}\text { Monthly Household income } \\
\text { (US dollar) }\end{array}$} & Below 1685 & & \\
\hline Gender & Female & & & & 1685 to 2527 & & \\
\hline \multirow{6}{*}{ Age } & $20 \sim 29$ & 84 & 16 & & 2527 to 3370 & 84 & 16 \\
\hline & $30 \sim 39$ & 72 & 13 & & 3370 to 4212 & 76 & 14 \\
\hline & $40 \sim 49$ & 134 & 25 & & 4212 to 5055 & 104 & 19 \\
\hline & $50 \sim 59$ & 100 & 19 & & Over 5055 & 139 & 26 \\
\hline & $60 \sim 69$ & 109 & 20 & \multirow{3}{*}{ Presence of respiratory disease } & No & 316 & 59 \\
\hline & Over 70 & 36 & 7 & & 1 No & & \\
\hline \multirow{2}{*}{ Marriage } & No & 206 & 39 & & Yes & 219 & 41 \\
\hline & Yes & 329 & 61 & \multirow{2}{*}{$\begin{array}{l}\text { Considering farming or returning } \\
\text { to rural after retirement }\end{array}$} & No & 233 & 44 \\
\hline \multirow{4}{*}{ Education } & $\begin{array}{l}\text { Under high } \\
\text { school }\end{array}$ & 80 & 15 & & Yes & 302 & 56 \\
\hline & University & 394 & 74 & \multirow{3}{*}{ Need for city improvement } & Yes & 272 & 51 \\
\hline & Graduate and & 61 & 11 & & No & 79 & 15 \\
\hline & above & 01 & 11 & & Don't know & 184 & 34 \\
\hline \multirow{5}{*}{$\begin{array}{c}\text { Number of } \\
\text { Household } \\
\text { members living } \\
\text { together }\end{array}$} & 1 & 81 & 15 & \multirow{2}{*}{ Having children under age of 8} & No & 471 & 88 \\
\hline & 2 & 102 & 19 & & Yes & 64 & 12 \\
\hline & 3 & 181 & 34 & \multirow{2}{*}{$\begin{array}{l}\text { Awareness of urban regeneration } \\
\text { projects using wood }\end{array}$} & Aware of it & 204 & 38 \\
\hline & 4 & 149 & 28 & & Don't know & 331 & 62 \\
\hline & Over 5 & 22 & 4 & \multirow{4}{*}{ Preferred building material } & Glass & 55 & 10 \\
\hline \multirow{7}{*}{ Occupation } & Student & 45 & 9 & & Concrete & 55 & 10 \\
\hline & Housewife & 68 & 13 & & Wood & 370 & 70 \\
\hline & Employee & 280 & 52 & & Iron frame & 55 & 10 \\
\hline & $\begin{array}{l}\text { Professor and } \\
\text { researchers }\end{array}$ & 4 & 0 & \multirow{4}{*}{ Experience of visiting Seoullo } & Yes & 248 & 46 \\
\hline & $\begin{array}{l}\text { Government } \\
\text { officials }\end{array}$ & 2 & 0 & & No & 270 & 51 \\
\hline & Self-employed & 69 & 13 & & Don't know & 17 & 3 \\
\hline & others & 67 & 13 & & DOH L KIOW & 17 & 3 \\
\hline
\end{tabular}

In terms of the presence of respiratory disease and preference for building materials, $59 \%$ and $70 \%$ of respondents have the respiratory disease and prefer wood. A total of 302 respondents (56\%) respond that they consider farming or returning to a rural area after retirement. While $51 \%$ of the respondents express the need for city improvement, $62 \%$ of the respondents respond that they are not aware of urban regeneration projects using wood. Finally, $46 \%$ of respondents respond that they have the experience of visiting Seoullo.

\section{Results}

The estimation result of the conditional logit model and marginal WTP for all respondents are presented in this section. The results dividing respondents into subgroups are also reported to investigate WTP differences incurred by the socioeconomic characteristics. 


\subsection{For All Respondents}

As a result of conducting a survey on all respondents, positive coefficients are estimated for all five attributes, including a bench, a floor, a flowerpot, public facilities, and a bridge fence. All coefficients are found to be significant at the $1 \%$ level. In the conditional logit analysis, we set concrete material for five attributes as the base model (i.e., dummy coding of 0 is applied for these). The result shows that the utility for wooden public facilities is found to be 0.3417 greater than that of concrete public facilities. Moreover, the utility for wooden flowerpots is found to be 0.2814 greater than that of concrete flowerpots (refer to Table 3). If the price (one-time tax) increases by KRW 2000, which amounts to USD 1.8 dollars, the utility decreases by 0.0001 . This result is consistent with the economic theory that the utility of the consumer decreases as the price increases.

Table 3. Conditional Logit estimation result and Marginal WTP for all respondents.

\begin{tabular}{ccc}
\hline Variables & Coefficients & $\begin{array}{c}\text { Marginal WTP for Wood } \\
\text { Material (USD) }\end{array}$ \\
\hline Bench $\left(\beta_{1}\right)$ & $0.1880^{* * *}$ & $1.19^{* * *}$ \\
Floor $\left(\beta_{2}\right)$ & $0.2563^{* * *}$ & $1.62^{* * *}$ \\
Flowerpot $\left(\beta_{3}\right)$ & $0.2814^{* * *}$ & $1.78^{* * *}$ \\
Public facilities $\left(\beta_{4}\right)$ & $0.3417^{* * *}$ & $2.16^{* * *}$ \\
Bridge fence $\left(\beta_{5}\right)$ & $0.2791^{* * *}$ & $1.77^{* * *}$ \\
Price (one-time tax) $\left(\beta_{6}\right)$ & $-0.0001^{* * *}$ & - \\
\hline Note: ${ }^{* * *}$ denote significant at $1 \%$. &
\end{tabular}

The marginal willingness to pay for each attribute is calculated by dividing the estimated coefficient of each attribute by the price coefficient. The attribute with the largest marginal WTP for wood material is public facilities, followed by a flowerpot, bridge fence, floor, and bench.

The total benefit for constructing Seoullo with wood material is calculated by multiplying the aggregated marginal WTP of five attributes by the number of households in Seoul. Under the tax exemption law, people with disabilities, people of national merit, and the wounded in the May 18 Democratic Movement are exempt from tax. Therefore, scenario analysis is conducted considering the households exempted from tax. Scenarios A, $\mathrm{B}$, and $\mathrm{C}$ assume that the proportion of the population who are eligible for tax exemption are $10 \%, 20 \%$, and $30 \%$, respectively.

The respondents who choose the no choice option do not prefer presented attribute profiles A and B. This implies that the respondents in this group are not satisfied with the combination of attributes considering the suggested price. Respondents who choose the no choice option for seven or eight times out of eight questions can be considered as having lower utility than the respondents who choose options A or B. Thus, those who mostly choose the no choice option are likely to feel a lower utility than the one calculated in Table 4. To reflect this, total benefits reflecting the lower utility of respondents who choose no option are calculated by applying scenarios 1,2 , and 3. Scenario 1 represents the respondents who choose no option who feel the same utility as respondents who did not choose no option. Scenarios 2 and 3 represent the respondents who choose no option who feel lower in utility by $25 \%$ and $50 \%$, respectively. The total benefit to Seoul for the five attributes is estimated to be 11-30 million dollars, depending on scenarios 1 to 3 and scenarios A to C.

The result of the benefit-cost analysis is derived from dividing the total benefit of Seoullo by the total construction cost. Since the total construction cost to Seoul is estimated to be $0.6-0.8$ million according to scenarios 1,2 , and 3 , the $\mathrm{B} / \mathrm{C}$ ratio is calculated to be 15 to 50 according to cost and benefit scenarios, as indicated by Table 5 . This implies that the benefits that consumers feel are significantly greater than that of the cost. 
Table 4. Total benefits of Seoullo by Scenario, Unit: USD Dollars.

\begin{tabular}{cccc}
\hline Variables & Scenario A & Scenario B & Scenario C \\
\hline Bench & $4,225,705$ & $3,756,183$ & $3,286,660$ \\
Floor & $5,762,053$ & $5,121,825$ & $4,480,842$ \\
Flowerpot & $6,324,016$ & $5,622,295$ & $4,919,508$ \\
Public facilities & $7,678,745$ & $6,825,551$ & $5,972,357$ \\
Bridge fence & $6,274,169$ & $5,576,100$ & $4,879,087$ \\
\hline Total Benefits A-1 & $30,260,654$ & $26,898,359$ & $23,536,064$ \\
$\quad$ (Scenario 1) & $22,695,491$ & $20,173,769$ & $17,652,048$ \\
Total Benefits A-2 & & & $11,768,032$ \\
$\quad$ (Scenario 2) & $15,130,327$ & $13,449,180$ & \\
Total Benefits A-3 & & &
\end{tabular}

Note: 1. Scenarios A, B, and C are calculated by multiplying marginal WTP and the number of households in Seoul with $0.9,0.8$, and 0.7, respectively.; 2 . Total Benefit A-1, A-2, and A-3 are calculated by multiplying scenario A value with $1,0.75$, and 0.5 which accounts for the lower utility of respondents who chose no option.

Table 5. Results of B/C ratio by Scenario.

\begin{tabular}{cccc}
\hline Variables & Cost Scenario 1 & Cost Scenario 2 & Cost Scenario 3 \\
\hline Benefit scenario A-1 & $51.30^{*}$ & $44.89^{*}$ & $39.90^{*}$ \\
Benefit scenario A-2 & $38.48^{*}$ & $33.67^{*}$ & $29.93^{*}$ \\
Benefit scenario A-3 & $25.65^{*}$ & $22.45^{*}$ & $19.95^{*}$ \\
\hline Benefit scenario B-1 & $45.60^{*}$ & $39.90^{*}$ & $35.47 *$ \\
Benefit scenario B-2 & $34.20^{*}$ & $29.93^{*}$ & $26.60^{*}$ \\
Benefit scenario B-3 & $22.80^{*}$ & $19.95^{*}$ & $17.73^{*}$ \\
\hline Benefit scenario C-1 & $39.90^{*}$ & $34.92^{*}$ & $31.04^{*}$ \\
Benefit scenario C-2 & $29.93^{*}$ & $26.19 *$ & $23.28^{*}$ \\
Benefit scenario C-3 & $19.95^{*}$ & $17.46^{*}$ & $15.52^{*}$ \\
\hline
\end{tabular}

Note: $1 .{ }^{*}$ denotes economic feasibility is satisfied; 2 . Benefit Scenario A, B, and C are calculated by assuming $10 \%$, $20 \%$, and $30 \%$ of households eligible for tax exemption; 3 . Cost Scenario 1, 2, and 3 are calculated by assuming the cost to be USD 589,821; 674,082; and 758,342 dollars, respectively; 4 . Total Benefit A-1, A-2, and A-3 are calculated by multiplying scenario A value with $1,0.75$, and 0.5 which accounts for the lower utility of respondents who chose no option.

\subsection{Estimation Results for Subgroups}

The subgroup respondents that are sensitive to health are respondents with children under the age of 8 , respondents with respiratory disease, and respondents considering farming or returning to a rural area after retirement. The hypothesis is set for testing whether respondents of these subgroups are willing to pay more for environmental-friendly park facilities built with wood. The second hypothesis is that respondents who are aware of the urban regeneration project using wood and have experience of visiting Seoullo are likely to have more interest in the government's urban regeneration project. Respondents in need of city improvement and respondents who chose wood as a preferred building material are likely to have a great interest in improving the quality of life. The third hypothesis is set to test whether respondents of these subgroups are willing to pay more for Seoullo using wood. To sum up, these seven subgroups of respondents with different socioeconomic characteristics are expected to have a higher willingness to pay for Seoullo built with wood rather than concrete.

4.2.1. Results Dividing Respondents into Subgroups Based on Having Children under the Age of 8 or Not

In the case of respondents with a child under the age of 8 , the estimated coefficients are significant at the $5 \%$ level for public facilities and the price (refer to Table 6). This is a reasonable result because the information center provides services such as distribute booklets necessary for learning and provides guidance which increases the utility of parents with children. On the other hand, respondents with no children under the age of 8 are 
found to be significant for five attributes and price. This result shows that utility for wooden public facilities is found to be 0.3468 and 0.3295 greater than that of the concrete public facilities for the respondents with no child and with children under the age of 8 .

Table 6. Conditional Logit estimation result and Marginal WTP based on having Children under age of 8 or not.

\begin{tabular}{|c|c|c|c|c|}
\hline Variables & $\begin{array}{l}\text { Coefficients for } \\
\text { Respondents with No } \\
\text { Child under Age of } 8\end{array}$ & $\begin{array}{c}\text { Coefficients for } \\
\text { Respondents with } \\
\text { Children under Age of } 8\end{array}$ & $\begin{array}{c}\text { Marginal WTP for } \\
\text { Respondents with No } \\
\text { Child under Age of } 8 \\
\text { (USD) }\end{array}$ & $\begin{array}{l}\text { Marginal WTP for } \\
\text { Respondents with } \\
\text { Children under Age of } 8 \\
\text { (USD) }\end{array}$ \\
\hline Bench $\left(\beta_{1}\right)$ & $0.2283^{* * *}$ & 0.0444 & $1.33 * * *$ & 0.40 \\
\hline Floor $\left(\beta_{2}\right)$ & $0.2679^{* * *}$ & 0.2045 & $1.55^{* * *}$ & 1.86 \\
\hline Flowerpot $\left(\beta_{3}\right)$ & $0.3261^{* * *}$ & 0.1100 & $1.89^{* * *}$ & 1.00 \\
\hline Public facilities $\left(\beta_{4}\right)$ & $0.3468^{* * *}$ & $0.3295^{* *}$ & $2.01 * * *$ & $2.99 * *$ \\
\hline Bridge fence $\left(\beta_{5}\right)$ & $0.3055^{* * *}$ & 0.1797 & $1.77^{* * *}$ & 1.63 \\
\hline Price (one-time tax) $\left(\beta_{6}\right)$ & $-0.0002^{* * *}$ & $-0.0001^{* *}$ & & \\
\hline
\end{tabular}

Note: ${ }^{* *}$ and ${ }^{* *}$ denote significance at $1 \%$ and $5 \%$, respectively.

Contrary to the expectation, it is found that respondents with a child under the age of 8 have a lower willingness to pay for four attributes made using wood except for public facilities than those in the opposite group. This can be interpreted as the respondents with children under the age of 8 are more sensitive to tax payment and feel a greater burden of the cost relative to their preference for wood. The previous research suggests that a household with children spends $21.7 \%$ of living costs as an average monthly childcare expense [35]. Therefore, the disposable income excluding childcare expenditure for a family with children is significantly lower than that of a family without children.

\subsubsection{Results Dividing Respondents into Subgroups Based on the Presence of} Respiratory Disease

As indicated by Table 7, the estimated values of respondents who have and do not have the respiratory disease are significant for all five attributes. This implies that both groups of respondents have accepted the use of wood positively. The marginal WTP of respondents with respiratory disease turn out to have a lower willingness to pay for a wooden bench, floor, public facilities, and bridge fence than those in the opposite group. Due to the emergence of fine dust in recent years, the increasing attention on respiratory diseases has increased the concern for health, which results in spending more money on the prevention of various diseases. According to the OECD statistics, the Korean medical expenses per capita in 2018 were increased by 1.4 times compared to that of 2013 (USD 2128.8 dollars). This shows that medical expenses have increased to prevent various diseases in advance, as the great interest and concern for health increase among citizens. Thus, citizens without the disease are likely to pay more for health-related issues for prevention.

Table 7. Conditional Logit estimation result and Marginal WTP by whether or not having respiratory disease.

\begin{tabular}{|c|c|c|c|c|}
\hline Variables & $\begin{array}{l}\text { Coefficients for } \\
\text { Respondents with No } \\
\text { Respiratory Disease }\end{array}$ & $\begin{array}{c}\text { Coefficients for } \\
\text { Respondents with } \\
\text { Respiratory Disease }\end{array}$ & $\begin{array}{c}\text { Marginal WTP for } \\
\text { Respondents with No } \\
\text { Respiratory Disease } \\
\text { (USD) }\end{array}$ & $\begin{array}{l}\text { Marginal WTP for } \\
\text { Respondents with } \\
\text { Respiratory Disease } \\
\text { (USD) }\end{array}$ \\
\hline $\operatorname{Bench}\left(\beta_{1}\right)$ & $0.1898^{* * *}$ & $0.1864 * *$ & $1.27 * * *$ & $1.07 * *$ \\
\hline Floor $\left(\beta_{2}\right)$ & $0.2932 * * *$ & $0.1912 *$ & $1.96^{* *}$ & 1.10 \\
\hline Flowerpot $\left(\beta_{3}\right)$ & $0.2467 * * *$ & $0.3413^{* * *}$ & $1.65^{* * *}$ & $1.96^{* * *}$ \\
\hline Public facilities $\left(\beta_{4}\right)$ & $0.3305^{* * *}$ & $0.3613^{* * *}$ & $2.21^{* * *}$ & $2.07^{* *}$ \\
\hline Bridge fence $\left(\beta_{5}\right)$ & $0.2765^{* * *}$ & $0.2858^{* * *}$ & $1.85^{* * *}$ & $1.64^{* * *}$ \\
\hline Price (one-time tax) $\left(\beta_{6}\right)$ & $-0.0001^{* * *}$ & $-0.0002^{* * *}$ & & \\
\hline
\end{tabular}

Note: ${ }^{* * *}, * *$ and $*$ denote significance at 1,5 , and $10 \%$, respectively. 
4.2.3. Results Dividing Respondents into Subgroups Based on Considering Farming or Returning to Rural after Retirement

The estimated values of respondents who consider farming or returning to rural areas are significant for all five attributes and the price (refer to Table 8). The utilities for a wooden bench, a flowerpot, public facilities, and a bridge fence are greater than that of the concrete material for respondents who consider and do not consider farming or returning to rural areas. The marginal WTP of respondents who consider farming or returning to rural areas have a greater willingness to pay for wooden floors, a flowerpot, public facilities, and a bridge fence than those in the opposite group. This implies that the respondents who consider farming or returning to rural areas are more concerned about the health and prefer environmental-friendly construction materials. Therefore, the willingness to pay for wood is higher for this group.

Table 8. Conditional Logit estimation result and Marginal WTP by whether or not considering farming or returning to rural after retirement.

\begin{tabular}{|c|c|c|c|c|}
\hline Variables & $\begin{array}{c}\text { Coefficients for } \\
\text { Respondents with No } \\
\text { Consideration of } \\
\text { Farming or Returning to } \\
\text { Rural after Retirement }\end{array}$ & $\begin{array}{c}\text { Coefficients for } \\
\text { Respondents with } \\
\text { Consideration of } \\
\text { Farming or Returning to } \\
\text { Rural after Retirement }\end{array}$ & $\begin{array}{l}\text { Marginal WTP for } \\
\text { Respondents with No } \\
\text { Consideration of } \\
\text { Farming or Returning to } \\
\text { Rural after Retirement } \\
\text { (USD) }\end{array}$ & $\begin{array}{l}\text { Marginal WTP for } \\
\text { Respondents with } \\
\text { Consideration of } \\
\text { Farming or Returning to } \\
\text { Rural after Retirement } \\
\text { (USD) }\end{array}$ \\
\hline $\operatorname{Bench}\left(\beta_{1}\right)$ & $0.2187^{* * *}$ & $0.1694^{* *}$ & $1.23^{* *}$ & $1.16^{* *}$ \\
\hline Floor $\left(\beta_{2}\right)$ & 0.1407 & $0.3282 * * *$ & 0.79 & $2.24 * *$ \\
\hline Flowerpot $\left(\beta_{3}\right)$ & $0.3135^{* * *}$ & $0.2618^{* * *}$ & $1.76^{* * *}$ & $1.79 * * *$ \\
\hline Public facilities $\left(\beta_{4}\right)$ & $0.2948^{* * *}$ & $0.3722 * * *$ & $1.66^{* *}$ & $2.54^{* * *}$ \\
\hline Bridge fence $\left(\beta_{5}\right)$ & $0.2913 * * *$ & $0.2720 * * *$ & $1.64^{* * *}$ & $1.86^{* * *}$ \\
\hline Price (one-time tax) $\left(\beta_{6}\right)$ & $-0.0002^{* * *}$ & $-0.0001^{* * *}$ & - & - \\
\hline
\end{tabular}

Note: ${ }^{* * *}$ and $* *$ denote significance at $1 \%$ and $5 \%$, respectively.

4.2.4. Results Dividing Respondents into Subgroups Based on the Awareness of Urban Regeneration Project Using Wood

It is found that the estimated values of respondents who are aware and unaware of the urban regeneration project using wood are significant for all five attributes and prices (refer to Table 9). This suggests that both groups of respondents have accepted the use of wood positively. The result shows that the utility of the wooden bench is found to be 0.2797 higher than that of the concrete bench in the case of respondents who are not aware of the urban regeneration project using wood.

Table 9. Conditional Logit estimation result and Marginal WTP by whether or not having awareness of urban regeneration projects using wood.

\begin{tabular}{|c|c|c|c|c|}
\hline Variables & $\begin{array}{c}\text { Coefficients for } \\
\text { Respondents Who Are } \\
\text { Aware of Urban } \\
\text { Regeneration Projects } \\
\text { Using Wood }\end{array}$ & $\begin{array}{c}\text { Coefficients for } \\
\text { Respondents Who Are } \\
\text { Not Aware of Urban } \\
\text { Regeneration Projects } \\
\text { Using Wood }\end{array}$ & $\begin{array}{l}\text { Marginal WTP for } \\
\text { Respondents Who Are } \\
\text { Aware of Urban } \\
\text { Regeneration Projects } \\
\text { Using Wood (USD) }\end{array}$ & $\begin{array}{l}\text { Marginal WTP for } \\
\text { Respondents Who Are } \\
\text { Not Aware of Urban } \\
\text { Regeneration Projects } \\
\text { Using Wood (USD) }\end{array}$ \\
\hline Bench $\left(\beta_{1}\right)$ & 0.1536 ** & $0.2797^{* * *}$ & $1.20 * * *$ & $1.32 * * *$ \\
\hline Floor $\left(\beta_{2}\right)$ & $0.1956^{* *}$ & $0.3449^{* * *}$ & $1.52 *$ & $1.63^{* *}$ \\
\hline Flowerpot $\left(\beta_{3}\right)$ & $0.1950 * * *$ & $0.4172 * * *$ & $1.52 * * *$ & $1.97 * * *$ \\
\hline Public facilities $\left(\beta_{4}\right)$ & $0.2055^{* * *}$ & $0.5780^{* * *}$ & $1.60 *$ & $2.73^{* * *}$ \\
\hline Bridge fence $\left(\beta_{5}\right)$ & $0.1854 * * *$ & $0.4411^{* * *}$ & $1.44^{* * *}$ & $2.08 * * *$ \\
\hline Price (one-time tax) $\left(\beta_{6}\right)$ & $-0.0001 * * *$ & $-0.0001^{* * *}$ & - & - \\
\hline
\end{tabular}

The marginal WTP of all five attributes is significant for both respondent groups. However, it is found that the estimated values of all five attributes are lower for the respondents who are aware of urban regeneration projects using wood. In the case of citizens who do not have prior knowledge about urban regeneration projects, it is highly 
likely that they do not have positive or negative prior information about urban regeneration projects. On the other side, among the respondents who are aware of the project, the amount of willingness to pay might differ depending on the positive or negative prior information that they have received. In other words, while the marginal WTP of citizens who receive positive information is likely to show a higher value, the marginal WTP of citizens who receive negative information is likely to be lower.

Thus, we can interpret that the marginal WTP for respondents who are not aware of the project is higher due to the negative information received by citizens who are aware of the project.

\subsubsection{Results Dividing Respondents into Subgroups Based on the Experience of Visiting Seoullo}

As reported in Table 10, the estimated values for the respondents with and without the experience of visiting Seoullo are found to be significant for all five attributes and prices, which implies that both groups of respondents have accepted the use of wood positively. Estimation results suggest that the utilities for five attributes with wood are greater than that of the concrete material for the respondents with and without the experience of visiting Seoullo.

Table 10. Conditional Logit estimation result and Marginal WTP by whether or not having the experience of visiting Seoullo.

\begin{tabular}{|c|c|c|c|c|}
\hline Variables & $\begin{array}{c}\text { Coefficients for } \\
\text { Respondents with No } \\
\text { Experience of Visiting } \\
\text { Seoullo }\end{array}$ & $\begin{array}{c}\text { Coefficients for } \\
\text { Respondents with } \\
\text { Experience of Visiting } \\
\text { Seoullo }\end{array}$ & $\begin{array}{l}\text { Marginal WTP for } \\
\text { Respondents with No } \\
\text { Experience of Visiting } \\
\text { Seoullo (USD) }\end{array}$ & $\begin{array}{l}\text { Marginal WTP for } \\
\text { Respondents with } \\
\text { Experience of Visiting } \\
\text { Seoullo (USD) }\end{array}$ \\
\hline $\operatorname{Bench}\left(\beta_{1}\right)$ & $0.1547 * *$ & $0.2013^{* * *}$ & $0.89 *$ & $1.38^{* * *}$ \\
\hline Floor $\left(\beta_{2}\right)$ & $0.2374 * *$ & $0.2582 * * *$ & $1.37 *$ & $1.77^{*}$ \\
\hline Flowerpot $\left(\beta_{3}\right)$ & $0.3085^{* * *}$ & $0.2718^{* * *}$ & $1.78^{* * *}$ & $1.87^{* * *}$ \\
\hline Public facilities $\left(\beta_{4}\right)$ & $0.3435 * * *$ & $0.3241^{* * *}$ & $1.98^{* *}$ & $2.23 * *$ \\
\hline Bridge fence $\left(\beta_{5}\right)$ & $0.2948 * * *$ & $0.2751^{* * *}$ & $1.70 * * *$ & $1.89 * * *$ \\
\hline Price (one-time tax) $\left(\beta_{6}\right)$ & $-0.0002 * * *$ & $-0.0001^{* * *}$ & & \\
\hline
\end{tabular}

Note: ${ }^{* * *}, * *$, and $*$ denote significant at 1,5 , and $10 \%$, respectively.

The respondents who have the experience of visiting Seoullo have a greater willingness to pay for all five attributes than those in the opposite group. This implies that the respondents with the experience of visiting Seoullo have a greater interest in improvement in the quality of life by using the park. Therefore, the willingness to pay for a park made of wood is higher for this group.

4.2.6. Results Dividing Respondents into Subgroups Based on the Perception of the Need for City Improvement

As indicated by Table 11, the estimated values of respondents in need of city improvement are significant for all five attributes and the price. The utilities for a wooden bench, a flowerpot, public facilities, and a bridge fence are greater than that of the concrete material for respondents who need and do not need city improvement. If the price (one-time tax) increases by KRW 2000, which amounts to USD 1.8 dollars, the utility is estimated to decrease by 0.0001 for both groups.

The respondents in need of city improvement turn out to have a greater willingness to pay for wooden floors, public facilities, and a bridge fence than those in the opposite group. This suggests that the respondents in need of city improvement are more concerned about the health and have a greater interest in the improvement in the quality of life. Therefore, the willingness to pay for wood is higher for this group. 
Table 11. Conditional Logit estimation result and Marginal WTP by whether or not perceiving the need for city improvement.

\begin{tabular}{|c|c|c|c|c|}
\hline Variables & $\begin{array}{l}\text { Coefficients for } \\
\text { Respondents Who Do } \\
\text { Not Need City } \\
\text { Improvement }\end{array}$ & $\begin{array}{l}\text { Coefficients for } \\
\text { Respondents in Need of } \\
\text { City Improvement }\end{array}$ & $\begin{array}{c}\text { Marginal WTP for } \\
\text { Respondents Who Do } \\
\text { Not Need City } \\
\text { Improvement (USD) }\end{array}$ & $\begin{array}{c}\text { Marginal WTP for } \\
\text { Respondents in Need of } \\
\text { City Improvement (USD) }\end{array}$ \\
\hline Bench $\left(\beta_{1}\right)$ & $0.2884 * * *$ & $0.1174 *$ & $1.83^{* * *}$ & $0.74 *$ \\
\hline Floor $\left(\beta_{2}\right)$ & 0.1409 & $0.3426^{* * *}$ & 0.90 & $2.17^{* *}$ \\
\hline Flowerpot $\left(\beta_{3}\right)$ & $0.3671^{* * *}$ & $0.2238^{* * *}$ & $2.33^{* * *}$ & $1.42 * * *$ \\
\hline Public facilities $\left(\beta_{4}\right)$ & $0.1828 *$ & $0.4563^{* * *}$ & 1.16 & $2.89^{* * *}$ \\
\hline Bridge fence $\left(\beta_{5}\right)$ & $0.1966^{* *}$ & $0.3373^{* * *}$ & $1.25^{* *}$ & $2.13^{* * *}$ \\
\hline Price (one-time tax) $\left(\beta_{6}\right)$ & $-0.0001 * * *$ & $-0.0001^{* * *}$ & & \\
\hline
\end{tabular}

\subsubsection{Results Dividing Respondents into Subgroups Based on the Preferred Building Material}

The estimated values for the respondents who chose wood as a preferred building material are significant for all five attributes and the price (refer to Table 12). The utilities for five attributes are greater than that of the concrete material for respondents who chose wood as a preferred building material. As expected, it is found that respondents who chose wood as a preferred building material have a greater willingness to pay for all five attributes than those in the opposite group. This implies that the respondents who chose wood as a preferred building material are more concerned about the health and have a greater interest in the improvement in the quality of life.

Table 12. Conditional Logit estimation result and Marginal WTP by preferred building materials.

\begin{tabular}{|c|c|c|c|c|}
\hline Variables & $\begin{array}{l}\text { Coefficients for } \\
\text { Respondents Who Chose } \\
\text { Wood as Preferred } \\
\text { Building Material }\end{array}$ & $\begin{array}{c}\text { Coefficients for } \\
\text { Respondents Who Chose } \\
\text { Non-Wood as Preferred } \\
\text { Building Material }\end{array}$ & $\begin{array}{l}\text { Marginal WTP for } \\
\text { Respondents Who Chose } \\
\text { Wood as Preferred } \\
\text { Building Material (USD) }\end{array}$ & $\begin{array}{l}\text { Marginal WTP for } \\
\text { Respondents Who Chose } \\
\text { Non-Wood as Preferred } \\
\text { Building Material (USD) }\end{array}$ \\
\hline $\operatorname{Bench}\left(\beta_{1}\right)$ & $0.2437^{* * *}$ & 0.0567 & $1.84^{* * *}$ & 0.26 \\
\hline Floor $\left(\beta_{2}\right)$ & $0.3009 * * *$ & 0.1700 & $2.28 * *$ & 0.78 \\
\hline Flowerpot $\left(\beta_{3}\right)$ & $0.3060 * * *$ & $0.2291 * * *$ & $2.31 * * *$ & $1.06^{* * *}$ \\
\hline Public facilities $\left(\beta_{4}\right)$ & $0.4500 * * *$ & 0.0995 & $3.40 * * *$ & 0.46 \\
\hline Bridge fence $\left(\beta_{5}\right)$ & $0.3666^{* * *}$ & 0.0806 & $2.77^{* * *}$ & 0.37 \\
\hline Price (one-time tax) $\left(\beta_{6}\right)$ & $-0.0001 * * *$ & $-0.0002^{* * *}$ & - & - \\
\hline
\end{tabular}

Note: ${ }^{* * *}$ and ${ }^{* *}$ denote significance at $1 \%$ and $5 \%$, respectively.

\section{Conclusions}

With the increasing interest in environmental-friendly wooden materials, the government is paying attention to urban wood utilization for public buildings. This new urban regeneration project will not only revitalize the wooden industry but also be a way to respond to climate change. Reflecting on the positive perception of wood, the demand for wood and wood-based construction in Korea is increasing rapidly. Despite this trend, research on the effectiveness and economic feasibility of wooden buildings has not been actively conducted. Moreover, there has been a lack of research on how much consumers prefer urban regeneration projects using wood.

The urban regeneration project is a project that needs policy support rather than being promoted by market principles. Due to its nature as a public good, the project benefits not only a specific individual or group but benefits a large number of citizens. In this context, to provide the basis for policy promotion, it is necessary to analyze consumer preferences and the economic feasibility of the project in advance.

This study investigates the willingness of one-time tax payment by citizens currently living in Seoul when Seoullo uses wood as a material for covering the surface of the facilities. Overall, the results of the analysis show that Seoul citizens who participated in the survey feel a greater preference for wood than the tax burden. In other words, 
respondents are positively aware of the urban regeneration project using wood and are willing to pay for the cost.

The total benefit to Seoul for the five attributes is estimated to be 11-30 million dollars, depending on benefit scenarios A to C. The total construction cost to Seoul is estimated to be $0.6-0.8$ million according to the cost scenarios 1,2 , and 3 . As a result of the benefit-cost analysis, the $\mathrm{B} / \mathrm{C}$ ratio is calculated to be 15 to 50 . This implies that the benefits that consumers feel are significantly greater than that of the cost.

The results of marginal WTP of all five attributes for subgroup respondents are presented following seven socioeconomic characteristics. While respondents with children under the age of 8 and respondents with respiratory disease have a lower marginal willingness to pay than those in the opposite groups, respondents who consider farming or returning to rural areas have a greater marginal WTP than those in the opposite groups. The result for respondents with children under the age of 8 and respondents with respiratory disease is contrary to our hypothesis as well as the result from Conroy et al. [36] which claim that respondents have a positive perception of health impacts on the use of wood products in the buildings.

While the result shows that respondents who are aware of the urban regeneration project have a lower marginal willingness to pay than those in the opposite groups, respondents with the experience of visiting Seoullo have a greater marginal WTP than those in the opposite groups. The result for respondents who are aware of the urban regeneration project is contrary to our hypothesis as well as the result from Baig et al. [37] which states that visitors to the public park are willing to pay more as their awareness of the park increases.

Lastly, the result shows that respondents in need of city improvement and respondents who chose wood as a preferred building material have a greater marginal WTP than those in the opposite groups. This result is in line with our third hypothesis and the result from Lähtinen et al. [38] which states that the aesthetics and well-being believer group have a statistically significant positive willingness to live in houses made of wood.

The results of this study show that respondents who have children under the age of 8 , diseases, and awareness of the urban regeneration projects have a lower willingness to pay for Seoullo using the wood material. This suggests that publicity for urban regeneration projects targeting these groups of respondents is necessary. In addition, the results of the subgroup of respondents related to the awareness of urban regeneration projects show that the current publicity of urban regeneration projects does not play a sufficient role in promoting a positive influence over Seoul citizens' willingness to pay for wooden architecture.

This study fills the gap of existing literature by focusing on the preference of citizens toward the urban regeneration project which utilizes wood as the main construction material. However, this study has some limitations. Although using wood as a building material in construction is more eco-friendly, the discussion on whether wood is ultimately a sustainable material is necessary for further research. This is because there is a negative effect of not purifying the air due to logging, as the increase in the use of wood as a building material as well as positive effects of the carbon storage occur. Another limitation is that the one-time tax that citizens are willing to pay may not fully capture reality. This is because WTP is estimated under the hypothetical situation where Seoullo, which was already built using concrete materials, is built with wood. Moreover, there is a limitation that the costs and benefits used in the analysis of this study include only the direct economic effects of the urban regeneration project. A study on the economic feasibility that considers indirect factors such as environmental effects, social impacts caused by revitalizing the wood industry, and health factors would be needed for future study. Nevertheless, this paper is expected to be used as grounds for promoting and improving the policies regenerating the desolate areas.

The results in this paper suggest that to raise interest and awareness of urban regeneration projects, future research focusing on groups with a low preference for wood is 
needed. The impact of conveying different information has a great influence on estimating the amount of willingness to pay for an urban regeneration project. Therefore, additional research on examining the difference between the willingness to pay under the provision of various information incorporating environmental, economic, and health aspects and the amount of willingness to pay under the absence of the information would be needed in future research.

Author Contributions: Conceptualization, H.L. and B.-i.A.; methodology, H.L.; validation, H.L., B.-i.A., and C.-D.E.; writing-original draft preparation, H.L., writing review and editing, B.-i.A. collecting data, C.-D.E.; supervision, B.-i.A. All authors have read and agreed to the published version of the manuscript.

Funding: This research was funded by the National Institute of Forest Science, Korea forest service.

Institutional Review Board Statement: The study was conducted according to the guidelines of the Declaration of Helsinki, and approved by the Ethics Committee of Korea University.

Informed Consent Statement: Informed consent was obtained from all subjects involved in the study.

Data Availability Statement: Data sharing not applicable.

Conflicts of Interest: The authors declare no conflict of interest.

\section{References}

1. IEA. Global Energy \& CO2 Status Report; The International Energy Agency: Paris, France, 2017; pp. 1-15.

2. Roh, J.H. Future Perspective and Significance of Korean Wooden Architecture-Focused on the Current Status and Examples of Japanese Wooden Architecture. J. North-East Asian Cult. 2016, 47, 399-414.

3. Kang, M.H.; Joo, S.J. A Study on the Elements Affecting the Demand of Wooden House - Based on the Cognition of Ordinary People and Architectural Designers to Wooden House. J. Archit. Inst. Korea Plan. Des. 2007, 23, 21-28.

4. Gold, S.; Rubik, F. Consumer attitudes towards timber as a construction material and towards timber frame houses-Selected findings of a representative survey among the German population. J. Clean. Prod. 2009, 17, 303-309. [CrossRef]

5. Gustavsson, L.; Sathre, R. Variability in energy and carbon dioxide balances of wood and concrete building materials. Build. Environ. 2006, 41, 940-951. [CrossRef]

6. Buchanan, A.H.; Levine, S.B. Wood-based building materials and atmospheric carbon emissions. Environ. Sci. Policy 1999, 2, 427-437. [CrossRef]

7. Lippke, B.; Wilson, J.; Perez-Garcia, J.; Bowyer, J.; Meil, J. CORRIM: Life-cycle environmental performance of renewable building materials. For. Prod. J. 2004, 54, 8-19.

8. Eriksson, E.; Gillespie, A.R.; Gustavsson, L.; Langvall, O.; Olsson, M.; Sathre, R.; Stendahl, J. Integrated carbon analysis of forest management practices and wood substitution. Can. J. For. Res. 2007, 37, 671-681. [CrossRef]

9. Joseph, P. Tretsiakova-McNally, S. Sustainable Non-Metallic Building Materials. Sustainability 2010, 2, 400-427. [CrossRef]

10. Smith-Ramírez, C.; Castillo, J.; Armesto, J.J. Willingness of rural communities to reforest with native tree species in central Chile. Restor. Ecol. 2019, 27, 1401-1408. [CrossRef]

11. Zhang, Y.; Hussain, A.; Deng, J.; Letson, N. Public Attitudes Toward Urban Trees and Supporting Urban Tree Programs. Environ. Behav. 2007, 39, 797-814. [CrossRef]

12. Ramage, M.H.; Burridge, H.; Busse-Wicher, M.; Fereday, G.; Reynolds, T.; Shah, D.U.; Wu, G.; Yu, L.; Fleming, P.; Densley-Tingley, D.; et al. The wood from the trees: The use of timber in construction. Renew. Sustain. Energy Rev. 2017, 68, 333-359. [CrossRef]

13. Perera, C.; Auger, P.; Klein, J. Green consumption practices among young environmentalists: A practice theory perspective. J. Bus. Ethics 2018, 152, 843-864. [CrossRef]

14. Toppinen, A.; Sauru, M.; Pätäri, S.; Lähtinen, K.; Tuppura, A. Internal and external factors of competitiveness shaping the future of wooden multistorey construction in Finland and Sweden. Constr. Manag. Econ. 2019, 37, 201-216. [CrossRef]

15. Sprotles, G.B.; Kendall, E.L. A methodology for profiling consumers' decision making styles. J. Consum. Aff. 1986, 20, 267-279. [CrossRef]

16. Kylkilahti, E.; Berghäll, S.; Autio, M.; Nurminen, J.; Toivonen, R.; Lähtinen, K.; Vihemäki, H.; Franzini, F.; Toppinen, A. A consumer-driven bioeconomy in housing? Combining consumption style with students' perceptions of the use of wood in multi-storey buildings. Ambio 2020, 49, 1943-1957. [CrossRef] [PubMed]

17. Ouvrard, B.; Abildtrup, J.; Stenger, A. Nudging Acceptability for Wood Ash Recycling in Forests: A Choice Experiment. Ecol. Econ. 2020, 177, 1-20. [CrossRef]

18. Švajlenka, J.; Mária, K. Houses based on wood as an ecological and sustainable housing alternative-Case study. Sustainability 2018, 10, 1502. [CrossRef]

19. Jang, E.K.; Yoon, Y.C.; Cha, J.H. Carbon Storage and GHG Substitution Effect of Domestic Wood Products. In Proceedings of the 2012 Forest Science Joint Academic Conference, Jeju, Korea, 8-9 February 2012; pp. 619-621. 
20. Ribeiro, F.L. Urban Regeneration Economics: The case of Lisbon's old downtown. Int. J. Strateg. Prop. Manag. 2008, 12, $203-213$. [CrossRef]

21. Arrow, K.J.; Cropper, M.L.; Eads, G.C.; Hahn, R.W.; Lave, L.B.; Noll, R.G.; Portney, P.R.; Russell, M.; Schmalensee, R.; Smith, V.K.; et al. Is there a role for benefit-cost analysis in environmental, health, and safety regulation? Science 1996, 272, $221-222$. [CrossRef]

22. Jayantha, W.M.; Ming, C.C. The effect of urban redevelopment on retail shopping property values: A case study in Hong Kong. Int. J. Urban Sci. 2015, 19, 379-399. [CrossRef]

23. Devaux, N.; Berthold, E.; Dubé, J. Economic Impact of a Heritage Policy on Residential Property Values in a Historic District Context: The Case of the Old City of Quebec. Rev. Reg. Stud. 2018, 48, $279-297$.

24. Schofield, J.A. Cost-Benefit Analysis in Urban E Regional Planning; Routledge: London, UK, 1987; 270p.

25. Rosenfeld, Y.; Shohet, I.M. Decision support model for semi-automated selection of renovation alternatives. Autom. Constr. 1999, 8, 503-510. [CrossRef]

26. ODPM. Assessing the Impacts of Spatial Interventions: Regeneration, Renewal and Regional Development 'The 3Rs guidance'; Office of the Deputy Prime Minister: London, UK, 2004; 175p.

27. Bennett, J.; Blamey, R. The Choice Modelling Approach to Environmental Valuation; Edward Elgar: Northampton, MA, USA, 2001; $269 \mathrm{p}$.

28. Alfnes, F.; Guttormsen, A.G.; Steine, G.; Kolstad, K. Consumers' Willingness to Pay for the Color of Salmon: A Choice Experiment with Real Economic Incentives. Am. J. Agric. Econ. 2006, 88, 1050-1061. [CrossRef]

29. Kim, D.H.; Ahn, B.I.; Kim, E.G. Metropolitan Residents' Preferences and Willingness to Pay for a Life Zone Forest for Mitigating Heat Island Effects during Summer Season in Korea. Sustainability 2016, 8, 1. [CrossRef]

30. Schulz, N.; Breustedt, G.; Latacz-Lohmann, U. Assessing Farmers' Willingness to Accept "Greening”: Insights from a Discrete Choice Experiment in Germany. J. Agric. Econ. 2014, 65, 26-48. [CrossRef]

31. Cheon, J.M.; Yang, Y.J.; Yoon, Y.S.; Lee, E.S.; Lee, J.H.; Huh, Y.; Mun, M.J.; Jhung, C.H.; Hyun, B.R. Influence of Fine Particulate Dust Particulate Matter 10 on Respiratory Virus Infection in the Republic of Korea. Korean J. Fam. Pract. 2019, 9, 454-459. [CrossRef]

32. Cai, J.; Zhao, A.; Zhao, J.; Chen, R.; Wang, W.; Ha, S.; Xu, X.; Kan, H. Acute effects of air pollution on asthma hospitalization in Shanghai, China. Environ. Pollut. 2014, 191, 139-144. [CrossRef]

33. Marois, G.; Lord, S.; Negron-Poblete, P. The Residential Mobility of Seniors Among Different Residential Forms: Analysis of Metropolitan and Rural Issues for Six Contrasted Regions in Québec, Canada. J. Hous. Elder. 2018, 32, 73-98. [CrossRef]

34. Oh, H.; Jang, I.S.; Hwang, H.Y. Impacts of Awareness of Urban Regeneration Project on place attachment: Focused on Urban Regeneration project of Jungang-dong in Cheongju. J. Korean Assoc. Reg. Geogr. 2016, 22, 643-654.

35. Park, J.A. Childcare Expenditures of Families with Infant and Trends in Childcare Prices; Korea Institute of Child Care and Education: Seoul, Korea, 2016.

36. Conroy, K.; Riggio, M.; Knowles, C. Perceptions of the environmental and health impacts of wood product use in buildings: A survey among architects on the United States West Coast. BioProducts Bus. 2019, 4, 109-124.

37. Baig, A.; Ul Haq, Z.; Iqbal, J.; Amin, M.Y. Estimating Willingness to Pay for Parks: Evidence from a Developing country. Pak. J. Commer. Soc. Sci. 2019, 13, 1057-1067.

38. Lähtinen, K.; Harju, C.; Toppinen, A. Consumers' perceptions on the properties of wood affecting their willingness to live in and prejudices against houses made of timber. Wood Mater. Sci. Eng. 2019, 14, 325-331. [CrossRef] 